\title{
Pemaksimalan Papan Sirkuit Di Pandang Sebagai Masalah Planarisasi Graf 2-Layer Menggunakan Algoritma Genetika
}

\author{
Jusmawati Massalesse* ${ }^{*}$ dan Muh. Ali Imran**
}

\begin{abstract}
Abstrak
Tulisan ini dimaksudkan untuk menyelesaikan permasalahan pencetakan papan sirkuit 2-layer melalui suatu algoritma pencarian yang dikenal sebagai Algoritma Genetika. Tujuannya adalah mendapatkan jumlah jalur terbanyak yang dapat dicetak pada sebuah papan sirkuit 2 layer. Algoritma Genetika melakukan pencarian melalui proses evolusi tiruan dengan menggunakan suatu fungsi ukuran yang disebut fungsi fitness. Proses evolusi dilakukan melalui simulasi dengan bantuan komputer menggunakan software Mathlab. Representasi permasalahan dinyatakan dalam graf $\mathrm{K}_{\mathrm{n}}$. Di dalam tulisan ini, diambil graf $\mathrm{K}_{10}$ sebagai contoh kasus. Setelah dilakukan iterasi sejumlah 1500 kali diperoleh hasil bahwa nilai fitness tertinggi dicapai mulai pada iterasi ke 1000. Subgraf planar maksimal diperoleh dengan menghilangkan 7 sisi dari graf $\mathrm{K}_{10}$. Hal ini berarti bahwa apabila terdapat 10 konektor yang akan dicetak pada papan sirkuit 2layer maka jumlah jalur maksimal yang dapat dicetak adalah jumlah sisi $\mathrm{K}_{10}$ dikurangi 7 (45$7=38)$.
\end{abstract}

Kata Kunci : Algoritma Genetika, fungsi obyektif, fungsi fitness, graf planar.

\section{Pendahuluan}

Masalah planarisasi sampai sejauh ini masih merupakan masalah terbuka mengingat belum ditemukan suatu metode atau algoritma standar untuk menyusun kembali sisi-sisi graf menjadi tidak saling berpotongan.

Planarisasi graf satu layer telah dilakukan melalui penelitian sebelumnya yang berjudul Planarisasi graf dengan Algoritma Genetika. Berangkat dari hasil yang diperoleh pada penelitian tersebut, algoritma yang sama akan digunakan untuk menyelesaikan masalah planarisasi graf 2layer. Pada masalah planarisasi graf dua layer, Algoritma Genetika bekerja menemukan cara dalam menyusun sisi-sisi graf ke dalam dua layer dengan himpunan simpul yang sama pada kedua layer. Kromosom yang mewakili solusi memuat informasi mengenai peletakan sisi-sisi graf dan cara pemilihan sisi graf sehingga menjadi 2 subgraf planar dengan jumlah sisi maksimum.

Masalah planarisasi graf 2-layer terkait dengan penyusunan papan sirkuit elektronik, sehingga hasil yang diperoleh melalui penelitian ini di harapkan memberikan kontribusi di bidang teknologi, khususnya industri elektronik.

Metode yang digunakan banyak dikembangkan pada dekade belakangan ini, karena metode pencariannya hanya melibatkan fungsi obyektif dari permasalahan yang akan dikaji. Sifat

\footnotetext{
* Staf pengajar pada Jurusan Matematika F.MIPA Universitas Hasanuddin Makassar Jusmawati2004@yahoo.com

** Lulusan program studi Matematika Jurusan Matematika F.MIPA Universitas Hasanuddin Makassar
} 


\section{Jusmawati Massalesse, Muh. Ali Imran}

pencariannya yang probabilistik juga memungkinkan untuk menemukan solusi pendekatan untuk permasalahan yang tidak memiliki solusi eksak.

\section{Algoritma Genetika}

\subsection{Konsep dasar}

Secara umum penyelesaian masalah melalui Algoritma Genetika diawali dengan mengkode parameter permasalahan menjadi individu yang selanjutnya disebut kromosom. Kromosom ini akan berevolusi melalui operator-operator genetika sampai diperoleh kromosom terbaik, yaitu kromosom dengan nilai fitness paling tinggi. Disini, nilai fitness merupakan nilai yang menyatakan kesanggupan kromosom untuk eksis atau bertahan hidup sepanjang proses evolusi.

Operator genetika yang digunakan dalam penelitian ini adalah operator reproduksi, crossover dan mutasi. Dalam prakteknya, terdapat banyak metode reproduksi, crossover dan mutasi yang dapat digunakan, tetapi pada prinsipnya memiliki tujuan sebagai berikut:

\section{a. Reproduksi}

Operator reproduksi dimaksudkan untuk mempertahankan dan menggandakan individu terbaik di dalam populasi. Prosedur reproduksi dilakukan dengan menghitung nilai fitness, total fitness, peluang fitness dan peluang kumulatif untuk masing-masing kromosom di dalam populasi melalui rumus berikut:

$$
\begin{gathered}
\text { - Total fitnes }=\sum_{i=1}^{p} f_{f i t}(i), \\
p=\text { ukuran populasi. }
\end{gathered}
$$

- Peluang fitnes $(j)=\frac{f_{f i t}(j)}{\sum_{i=1}^{p} f_{f i t}(i)}$

- Peluang kumulatif $(j)=\sum_{i=1}^{i=j}$ Peluang fitnes $(j)$

b. Crossover atau penyilangan

Operator ini dikenakan terhadap populasi hasil reproduksi. Melalui operator ini diharapkan muncul individu baru yang masih memiliki sifat-sifat induknya.

\section{c. Mutasi}

Operator mutasi diperlukan untuk menampilkan keragaman individu yang kemungkinan tidak muncul melalui operator reproduksi dan persilangan saja.

Populasi yang telah melewati operator mutasi adalah populasi yang telah melewati satu kali proses evolusi. Populasi ini selanjutnya disebut Populasi Generasi Pertama. Proses evolusi dilakukan secara terus menerus sampai nilai fitness konvergen ke satu titik.

\subsection{Planarisasi Graf Dengan Algoritma Genetika}

Diberikan sebuah graf lengkap $\mathrm{K}_{n}$. Pengambilan ini didasarkan pada pertimbangan bahwa graf sederhana yang terdiri dari $n$ simpul yang memiliki sisi terbanyak adalah $\mathrm{K}_{n}$. Tujuan penelitian adalah mereduksi sisi $\mathrm{K}_{n}$ menjadi dua subgraf planar dengan himpunan $n$ simpul yang sama dengan jumlah sisi terbanyak.

Proses ini dimulai dengan mengkonstruksi dua graf, yaitu $G^{1}\left(V^{1}, E^{1}\right)$ dan $G^{2}\left(V^{2}, E^{2}\right)$ yang memenuhi syarat berikut: 


\section{Jusmawati Massalesse, Muh. Ali Imran}

- $\quad \mathrm{V}^{1}=\mathrm{V}^{2}=\mathrm{V}\left(\mathrm{K}_{\mathrm{n}}\right)$

- $\quad E^{1} \cap E^{2}=\varnothing$

- $\quad E^{1} \cup E^{2}=E\left(K_{n}\right), E^{1}, E^{2} \subseteq E\left(K_{n}\right)$

Graf $\mathrm{G}^{1}$ dan $\mathrm{G}^{2}$ masing-masing merupakan graf pada layer pertama dan layer kedua.

Pada proses pencarian yang menggunakan Algoritma Genetika, pengkodean parameter merupakan masalah utama yang harus diselesaikan terlebih dahulu sebelum mengenakan oparator-operator genetika. Jadi permasalahan pertama yang harus diselesaikan dalam memplanarkan graf adalah bagaimana mengkodekan graf menjadi parameter berbentuk kromosom. F. Comellas (1992) dalam jurnalnya yang berjudul "Using Genetic Algorithms for planarization Problem" menulis bahwa untuk melakukan pengkodean parameter, graf digambarkan dengan metode straight line sebagaimana diperlihatkan pada Gambar 1.

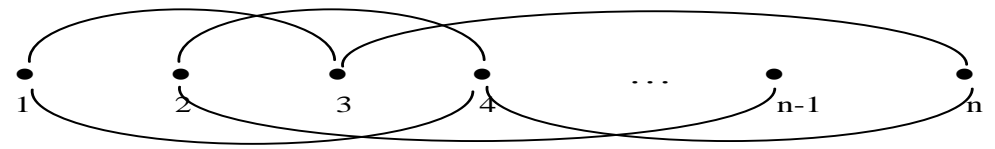

Gambar 1

Sisi-sisi dari graf diletakkan di sebelah atas (selanjutnya disebut sisi atas) atau di sebelah bawah (selanjutnya disebut sisi bawah). Sisi atas $(\mathrm{i}, \mathrm{j})$ dikodekan sebagai gen yang bernilai "1" sedangkan sisi bawah $(\mathrm{i}, \mathrm{j})$ dikodekan sebagai gen yang bernilai "-1". Jika pasangan simpul (i,j) bukan sisi maka nilai gen yang bersesuaian adalah "0".

Kromosom dibangun dengan cara sebagai berikut: misalkan diberikan sebuah graf dengan himpunan simpul $\mathrm{V}(\mathrm{G})=\{1,2, \ldots \mathrm{n}\}$ maka sebuah kromosom tersusun atas sisi-sisi $(\mathrm{i}, \mathrm{j})$ sebagai gen dengan urutan sebagai berikut:

\section{$(1,2)(1,3) \ldots(1, n)(2,3)(2,4) \ldots(2, n) \ldots \ldots \ldots . . .(n-2, n-1)(n-2, n)(n-1, n)$}

Di mana $(\mathrm{i}, \mathrm{j})$ bernilai "1" atau "-1" tergantung posisi sisi sebagai sisi atas atau sisi bawah.

\section{Pembahasan}

Simulasi proses evolusi oleh Algoritma Genetika dikenakan terhadap $\mathrm{K}_{10}$ sebagaimana diperlihatkan pada Gambar 2. Pemilihan graf ini tentu saja dapat dilakukan terhadap graf lengkap yang mempunyai simpul lebih banyak, disesuaikan dengan kemampuan komputer yang digunakan.

8

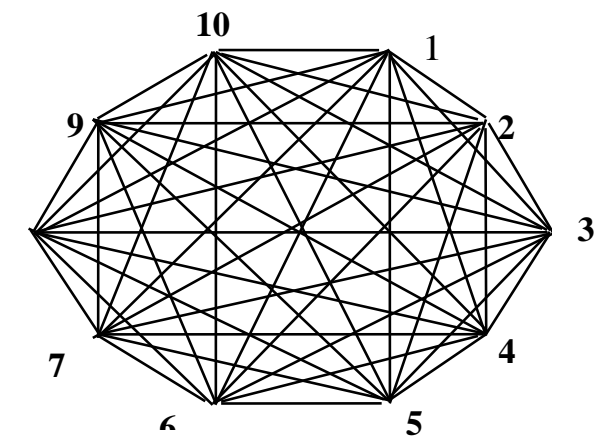

Gambar 2. Graf $\mathrm{K}_{10}$ 


\section{Jusmawati Massalesse, Muh. Ali Imran}

\section{Kode Parameter.}

Dengan metode straight-line, graf pada Gambar 2 dapat digambarkan menjadi $4^{45}=1.23794 \times 10^{27}$ cara yang berbeda, salah satu diantaranya sebagaimana diperlihatkan berikut ini:

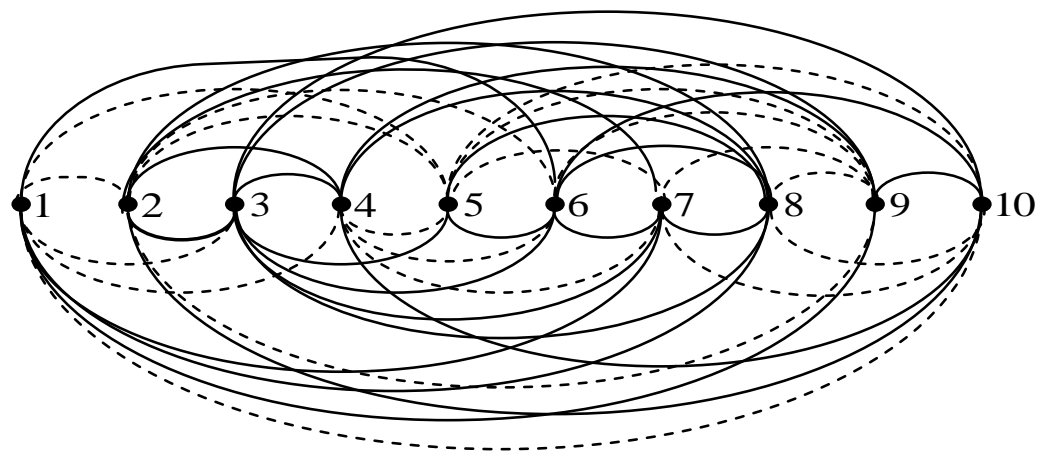

Gambar 3. $\mathrm{K}_{10}$ dengan metode straight-line

Kromosom yangbersesuaian dengan graf pada Gambar 3 adalah

\section{2-2-2-21-1-1-1-2-112211-2-11-1-1-1-111-2-2-211-1-12122-1121-12-22-21}

Jadi terdapat $1.23794 \times 10^{27}$ kombinasi kromosom berbeda yang dapat dibangkitkan dari graf $\mathrm{K}_{10}$. Sepanjang proses, apabila terdapat sisi yang berpotongan maka sisi tersebut akan dihilangkan dari graf. Nilai gen yang bersesuaian dengan sisi yang dihilangkan dari graf adalah " 0 ". Sehingga ruang solusi merupakan himpunan semua kromosom yang terdiri dari susunan 45 gen bernilai -2, $-1,0,1$ atau 2. Jadi ruang solusi terdiri dari $24^{5}=184528125$ kromosom. Proses evolusi akan melakukan pencarian pada ruang solusi untuk menemukan kromosom terbaik.

Proses evolusi diawali dengan membangkitkan populasi awal berukuran 100. Populasi awal ini dibangkitkan secara acak melalui program Matlab. Tabel 1 menampilkan 10 individu pertama pada populasi tersebut.

Tabel 1. Populasi Awal

\begin{tabular}{|c|c|}
\hline Kromosom & Populasi Awal \\
\hline 1 & $-2-1121-21-2-211211-1-2-2-11-11-1-1111-22-2-2-1-12-2-2-2-2211-2-112-1$ \\
\hline 2 & $212-2-22-2-2-212-2121-2-2-222-2-1-2-12-21-12-2-12-2-21-1-1-1212-1211$ \\
\hline 3 & $22-2211-1-1-111211-2-1-2-2-2-111-2-12-111-2-11-2-21111-22-2-21-1-22$ \\
\hline 4 & $22-2-21-11-21-2-2-1-2-1-1122221-2-21-1-111-2-211-2-2-22-1-1221-2-11-2$ \\
\hline 5 & $-1-2-112-112-1211221-12-22-11-1-1-12-1-222-1-1-2211-12-2-22-2-11-2-1$ \\
\hline 6 & $-1-2-2-11-2-11-2-1-1-2-2-1122-21-2-11-2-2-2-222-2-2-1212111-2-12-112-12$ \\
\hline 7 & $121-22-11-2-2-11-2-12-1-11-2-121-11212-21-21211-2-2-2-2-1-1-2-1-2-11-2$ \\
\hline 8 & $12-11-22111-1-12-2-1-12-1-221-22-212-2-22-2222-1-22-21-12122-22$ \\
\hline 9 & $211-2-1-22221-222-1112-222-21-2-2-1-1-22-212-22-2121-21-11211$ \\
\hline 10 & $-1-2-2221-22-22-12-2-122-2-1-21-1-12-212111-221-1-12111-212122-2$ \\
\hline
\end{tabular}




\section{Jusmawati Massalesse, Muh. Ali Imran}

\section{Fungsi Fitness}

Planarisasi graf berkaitan dengan reposisi sisi-sisi graf sehingga menjadi tidak berpotongan. Oleh karena itu, fungsi obyektif dapat dirumuskan sebagai sebuah persamaan fungsi sebagai berikut:

$$
f_{o b j}=v_{c} \cdot c_{c}+\left(M-v_{e} \cdot e_{c}\right)
$$

di mana:

$$
\begin{aligned}
& v_{c}=\text { bobot } c_{c} \\
& v_{e}=\text { bobot } e_{c} \\
& e_{c}=\text { jumlah perpotongan sisi } \\
& e_{c}=\text { jumlah sisi dalam graf } \\
& \mathrm{M}=\text { jumlah sisi graf lengkap 2-layer }
\end{aligned}
$$

Penentuan sisi berpotongan dilakukan sebagai berikut:

Misalkan $(i, j)$ dan $(k, l)$ adalah dua sisi pada graf, maka $(i, j)$ dan $(k, l)$ berpotongan jika $i<k<j<l$ atau $k<i<l<j$ dan nilai gennya sama.

Makin kecil nilai $f_{\text {oby }}$, makin baik kromosom yang bersesuaian. Karena fungsi fitness adalah fungsi yang menyatakan ukuran sehat atau tidaknya suatu kromosom, maka suatu kromosom yang memiliki nilai fitness lebih besar pastilah berkaitan dengan nilai $f_{\text {oby }}$ yang lebih kecil. Oleh karena itu, fungsi fitness dikonstruksi sebagai berikut:

$$
f_{f i t}=\frac{1}{f_{o b j}}
$$

Dari persamaan (1), dipilih bobot $v_{c}=1,6$ sedangkan bobot $\mathrm{v}_{\mathrm{e}}=1$, sehingga fungsi obyektif menjadi:

$$
f_{o b j}=1.6 \cdot c_{c}+\left(45-v_{c}\right)+3
$$

Penambahan faktor 3 pada persamaan (1) dimaksudkan untuk menghindari penyebut menjadi nol pada konstruksi fungsi fitness.

Hasil perhitungan dengan program Matlab berdasarkan populasi awal pada Tabel 1 dapat dilihat pada Tabel 2.

Tabel 2. Nilai objektif dan Fitness, Peluang fitness dan kumulatif.

\begin{tabular}{|c|c|c|c|c|c|}
\hline Individu & Nilai_obj & Nilai_fit & $\begin{array}{c}\text { Peluang_fi } \\
\mathbf{t}\end{array}$ & Peluang_kom & Bil. Acak r \\
\hline $\mathbf{( 1 )}$ & $\mathbf{( 2 )}$ & $\mathbf{( 3 )}$ & $\mathbf{( 4 )}$ & $\mathbf{( 5 )}$ & $\mathbf{( 6 )}$ \\
\hline 1 & 79.2000 & 0.0126 & 0.0181 & 0.0181 & 0.2748 \\
2 & 95.2000 & 0.0105 & 0.0151 & 0.0332 & 0.1255 \\
3 & 108.0000 & 0.0093 & 0.0133 & 0.0464 & 0.7584 \\
4 & 90.4000 & 0.0111 & 0.0159 & 0.0623 & 0.7654 \\
5 & 82.4000 & 0.0121 & 0.0174 & 0.0797 & 0.4305 \\
6 & 79.2000 & 0.0126 & 0.0181 & 0.0978 & 0.7559 \\
7 & 72.8000 & 0.0137 & 0.0197 & 0.1175 & 0.7492 \\
8 & 82.4000 & 0.0121 & 0.0174 & 0.1349 & 0.5676 \\
9 & 92.0000 & 0.0109 & 0.0156 & 0.1505 & 0.1073 \\
10 & 98.4000 & 0.0102 & 0.0146 & 0.1650 & 0.2094 \\
& & & & & \\
\hline
\end{tabular}




\section{Jusmawati Massalesse, Muh. Ali Imran}

\section{Operator Genetika}

\section{- Reproduksi roulette-wheel}

Model reproduksi yang digunakan disini adalah reproduksi roulette-wheel yang prosesnya mengikuti cara kerja meja roulette, dimana kromosom yang memiliki selisih peluang kumulatif lebih besar dengan kromosom sebelumnya berpeluang lebih besar untuk terseleksi kembali sebagai kromosom pada generasi selanjutnya. Proses seleksi dilakukan dengan membangkitkan bilangan acak $r$ sebanyak jumlah kromosom didalam populasi. Sepuluh bilangan acak r yang pertama ditampilkan pada kolom 6 Tabel 2. Hasil seleksi diperlihatkan pada Tabel 3.

Tabel 3. Populasi Hasil Reproduksi

\begin{tabular}{|c|c|}
\hline Individu & Kromosom \\
\hline 1 & $\begin{array}{c}1-112-1-12-12-1-1-1-1-11-112-1-2122-2-1-2222112-2-11112-2-11-1111 \\
-1-1-1\end{array}$ \\
\hline 2 & $\begin{array}{c}12-11-22111-1-1-12-2-1-1-2-1-221-22-212-2-22-2222-1-22-21-1212 \\
2-22\end{array}$ \\
\hline 3 & $\begin{array}{c}121-211-2-2-12-11111-22212-1-2-122111-12-2-22-21-1-21-12-21 \\
2-2-1\end{array}$ \\
\hline 4 & $\begin{array}{c}1121-221-2-2-12-111111-222112-1-2-1221111-12-2-22-21-1-21-12-21 \\
2-2-1\end{array}$ \\
\hline 5 & $\begin{array}{c}-1-1-2-2-1-212-1-2-221-2-1-2-2-2-2-222-121-21-2-221-1-2-2-1-2-221-21 \\
2222\end{array}$ \\
\hline 6 & $\begin{array}{c}121-211-2-2-12-11111-22212-1-2-1221111-12-2-22-21-1-21-12-21 \\
2-2-1\end{array}$ \\
\hline 7 & $\begin{array}{c}1-22-2-11-1111-12-2222-212-11-11112-1-1122-2-122211112-21-2 \\
12-1\end{array}$ \\
\hline 8 & $\begin{array}{c}-22-22-2-1-122221-22-1-1-22-1-22-2-1-2-2-21-1222-1-11112-2111-1-1-2 \\
1-1-2-2\end{array}$ \\
\hline 9 & $\begin{array}{c}121-22-11-2-2-11-2-12-1-11-2-121-11212-21-21211-2-2-2-2-1-1-2-1- \\
2-11-2\end{array}$ \\
\hline 10 & $\begin{array}{c}122-22-1121-2-2-12-2-1-11-1-2-1-11-1-1-22-12-12-1-22-11-121-21-1- \\
1-1-2-1\end{array}$ \\
\hline
\end{tabular}

\section{- Penyilangan one-cut point}

Penyilangan dengan metode one-cut point dilakukan dengan memasangkan kromosom secara acak, kemudian memilih 1 titik penyilangan yang akan menentukan posisi pemotongan kromosom. Misalkan kromosom ke-6 dan ke-10 terpilih sebagai pasangan pertama yang mengalami penyilangan, dan $\mathrm{r}=20$ adalah titik penyilangan.

\begin{tabular}{|c|c|}
\hline 6 & $121-211-2-2-12-11111-2221 \mid-1-2-122111-12-2-22-21-1-21-12-21-2-2-1$ \\
\hline 10 & $122-22-1121-2-2-12-2-1-11-1-2 \mid-1-11-1-1-22-12-12-1-22-11-121-21-1-1-1-2-1$ \\
\hline
\end{tabular}


Maka kromosom baru hasil penyilangan adalah:

\begin{tabular}{|l|l|l|l|}
\hline $1^{\prime}$ & $1-2-2-12-11111-2221$ & $-1-11-1-1-22-12-12-1-22-11-121-21-1-1-1-2-1$ \\
\hline $2^{\prime}$ & $1121-2-2-12-2-1-11-2$ & $-1-2-122111-12-2-22-21-1.21-12-21-2-2-1$ \\
\hline
\end{tabular}

\section{- Mutasi}

Didalam penelitian ini dipilih $\alpha=0.001$, yang berarti sekitar $1 \%$ gen di dalam populasi akan mengalami mutasi. Proses dimulai dengan membangkitkan bilangan random $r \in(0,1)$ sebanyak jumlah gen di dalam populasi. Gen yang bersesuaian dengan bilangan random $r \leq \alpha$ akan mengalami mutasi dengan cara merubah nilai gen tersebut menjadi nilai gen lain di dalam himpunan nilai gen $\{-2,-1,0,1,2\}$.

Proses evolusi secara lengkap mengikuti alur kerja berikut ini:

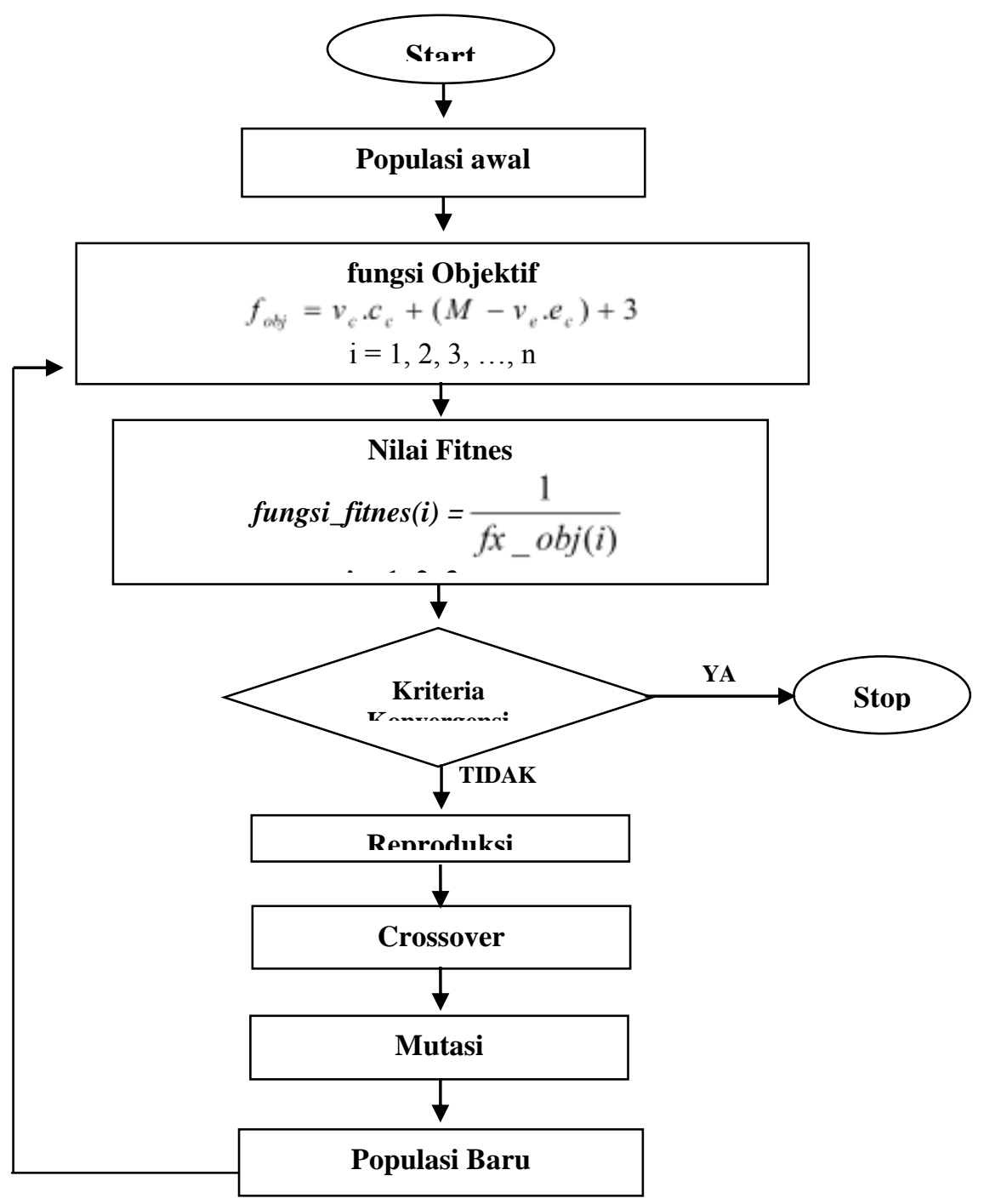

Gambar 4. Alur kerja proses evolusi 
Melalui program simulasi dilakukan iterasi sebanyak 2000 kali (2000 generasi). Pada setiap generasi dipilih kromosom terbaik kemudian diplot pada bidang dengan sumbu mendatar menyatakan generasi ke- sedangkan sumbu tegak menyatakan nilai fitness terbaik.

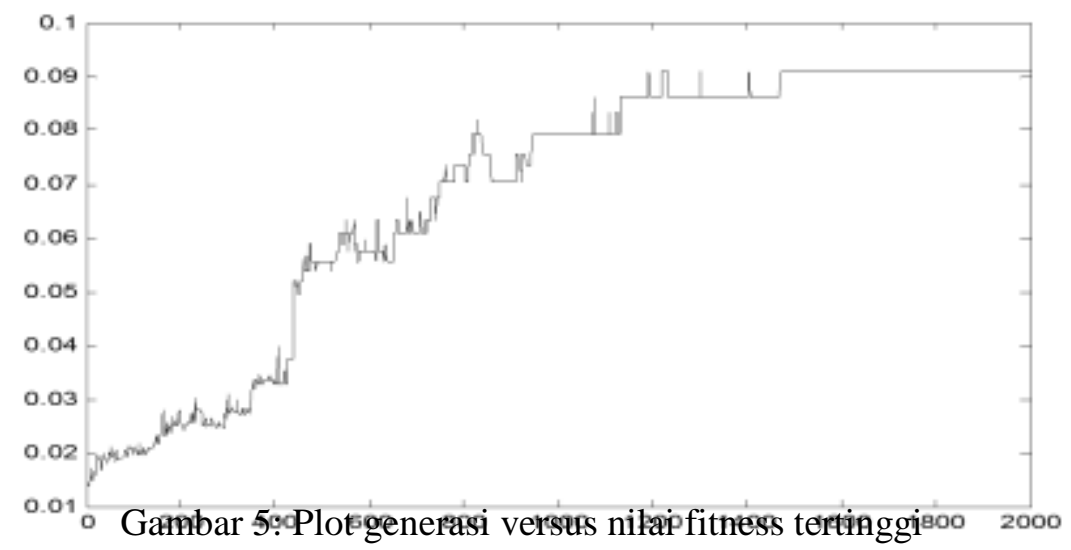

Grafik yang diperoleh menyatakan bahwa nilai fitness terbaik konvergen ke nilai fitness 0,0909. Nilai ini merupakan nilai fitness dari kromosom:

\section{$1-2-220-1-1-1-2-2220-10011-1-1-10112-2-211-2-10122-1120-12-22-21$}

Representasi graf 2-layer maksimal dari kromosom tersebut sebagaimana diperlihatkan pada Gambar 4.

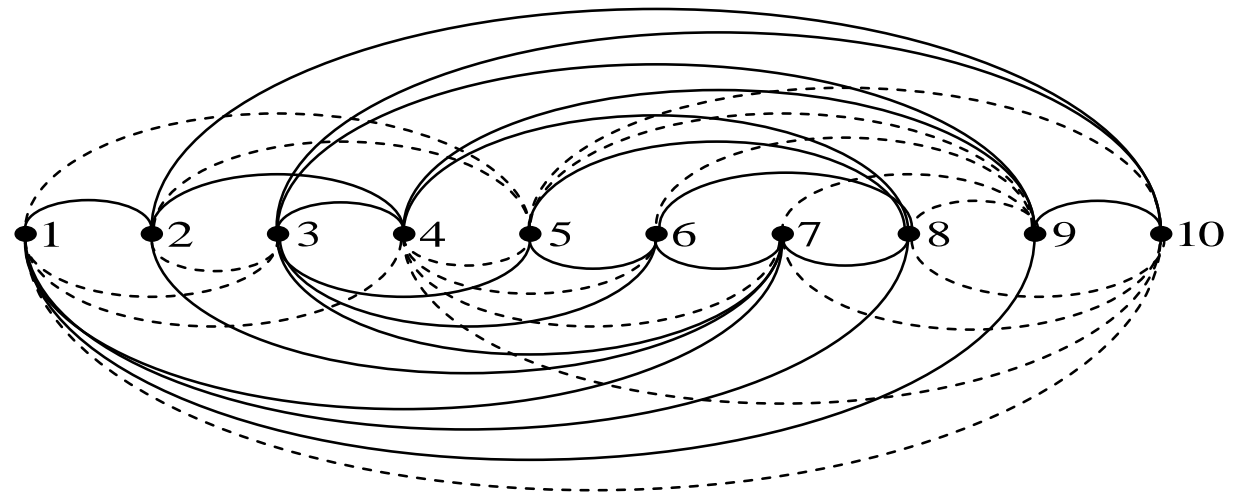

Gambar 6. Subgraf planar maksimal dari $\mathrm{K}_{10}$

\section{Kesimpulan}

Dari proses dan hasil yang diperoleh melalui running program simulasi yang disusun menggunakan software Matlab, ternyata pengambilan nilai parameter dan kemampuan komputer sangat menentukan pencapaian solusi. Beberapa hal yang menjadi perhatian adalah:

1. Pengambilan populasi awal yang berukuran kurang dari 100 menyebabkan jangkauan ruang solusi membutuhksan iterasi yang jauh lebih banyak dibandingkan dengan populasi yang berukuran 100. Sedangkan untuk ukuran populasi yang lebih besar dari 100, dibutuhkan waktu yang lama untuk menghasilkan output dalam satu kali running. Ukuran populasi yang ideal adalah 100, dan diperlukan minimal 1500 kali iterasi untuk mencapai solusi.

2. Proporsi jumlah gen yang mengalami mutasi yang terlalu kecil (mendekati nol) menyebabkan program tidak dapat konvergen ke suatu nilai tertentu, sedangkan pengambilan yang 


\section{Jusmawati Massalesse, Muh. Ali Imran}

mendekati nilai 1 mengakibatkan kerusakan kromosom, ditandai oleh nilai rata-rata fungsi fitness yang tidak monoton naik.

3. Graf planar 2-layer maksimal yang dihasilkan dengan menggunakan Algoritma Genetika adalah 45-7=38 sisi. Angka 45 adalah total jumlah sisi dari graf $\mathrm{K}_{10}$, sedangkan jumlah sisi yang dihilangkan dari graf dinyatakan oleh banyaknya gen bernilai 0 pada kromosom yang mewakili solusi.

\section{Ucapan Terima Kasih}

Penulis mengucapkan terima kasih kepada Lembaga Penelitian Universitas Hasanuddin yang telah memberikan bantuan dana melalui DIPA Universitas Hasanuddin dengan Surat Perjanjian Pelaksanaan Penelitian Nomor: 3844/J04.2/PM.05/2006 tanggal 1 Mei 2006

\section{Daftar Pustaka}

[1]. F. Comellas, 1992, "Using Genetic Algorithms for Planarization Problem", in C. Brezinski and U. Kulish (Editors): Computational and Applied Mathematics,I, Elsevier Science Publishers, 93-97.

[2]. Nora Hartsfield dan Gerhard Ringel, 1997, "Pearl in Graph Theory A comprehensive Introduction", Revised and Augmented, Academic Press, London.

[3]. Jusmawati Massalesse, 2005, “Pemakaian Algoritma Genetika Pada Masalah Planarisasi Graf”, Penelitian RUTIN pada Lembaga Penelitian Univ. Hasanuddin.

[4]. Robin J. Wilson dan John J. Watkins, 1990, “Graphs An Introductory Approach”, John Wiley \& Sons Inc. Canada. 